\title{
SISTEM PENDUKUNG KEPUTUSAN PEMILIHAN HOTEL DI KOTA SEMARANG BERBASIS WEB DENGAN METODE FUZZY ANALYTICAL HIERARCHY PROCESS (FAHP)
}

\author{
Anita Ika Nurcahyani, Indriyati, dan Priyo Sidik Sasongko \\ Jurusan Ilmu Komputer / Informatika, FSM Universitas Diponegoro \\ anita.nurcahyani@gmail.com
}

\begin{abstract}
ABSTRAK
Hotel merupakan salah satu fasilitas penunjang pariwisata di suatu kota. Keragaman hotel membuat wisatawan seringkali kesulitan dalam menentukan pilihan hotel yang sesuai dengan kebutuhan dan kriteria yang diinginkan. Situs mengenai hotel yang sudah ada hanya menampilkan informasi dan data hotel yang terdapat di Kota Semarang. Melalui sebuah aplikasi terkomputerisasi, dapat membantu menentukan prioritas pemilihan hotel. Tugas akhir ini menghasilkan Sistem Pendukung Keputusan berbasis web dengan metode Fuzzy Analytical Hierarchy Process (FAHP). Sistem ini dibangun dengan menggunakan model proses Software Defelopment Live Cycle (SDLC), bahasa pemrograman PHP dan penyimpanan data SQL Server. Hasil keluaran sistem ini berupa prioritas hotel terbaik di Kota Semarang. Dengan adanya SPK ini, masyarakat yang hendak menginap di hotel dapat lebih mudah dalam memilih hotel yang sesuai kebutuhan.
\end{abstract}

Kata kunci : Sistem Pendukung Keputusan, Software Defelopment Live Cycle (SDLC), FAHP, Hotel.

\section{PENDAHULUAN}

Keragaman hotel membuat wisatawan seringkali kesulitan dalam menentukan hotel yang sesuai dengan kebutuhan dan kriteria sehingga diperlukan suatu aplikasi pendukung keputusan yang dapat membantu user dalam menentukan hotel dengan suatu metode [2]. Penentuan prioritas pemilihan hotel memerlukan data akurat berbasis komputer sebagai dasar setiap pemberian keputusan dalam pemilihan hotel. Melalui sebuah aplikasi terkomputerisasi, maka analisis keputusan dapat dibantu dengan analisa komputer. Sistem tersebut dikenal dengan Sistem Pendukung Keputusan (SPK). SPK menggunakan data, memberikan antarmuka pengguna yang mudah, dan dapat menggabungkan pemikiran pengambilan keputusan.

SPK merupakan suatu model yang dibangun untuk menyelesaikan permasalahan yang terstruktur. Untuk itu diperlukan sebuah metode untuk mendukung Sistem Pendukung Keputusan yang dapat memecahkan permasalahan pemilihan hotel secara akurat dan objektif. Salah satu metode yang dapat digunakan dalam pengambilan keputusan adalah metode Analytical Hierarchy Process (AHP).

Prinsip kerja AHP adalah penyederhanaan suatu persoalan kompleks yang tidak terstruktur, strategis, dan dinamis menjadi bagian- bagiannya, serta menata dalam suatu hierarki [10]. Dengan hierarki, suatu masalah pemilihan hotel dapat diuraikan ke dalam kelompokkelompoknya yang kemudian diatur menjadi suatu bentuk hirarki sehingga permasalahan akan tampak lebih terstruktur dan sistematis. Selain itu, AHP juga dapat diintegrasikan dengan konsep himpunan fuzzy.

Selain itu, penambahan peta digital dapat memberikan kemudahan bagi masyarakat untuk mengetahui letak lokasi hotel. Sistem ini menggunakan media internet atau berbasis web, dimaksudkan agar dapat diakses secara luas oleh masyarakat secara online.

\section{FUZZY ANALYTICAL HIERARCHY}

Fuzzy Analytical Hierarchy Process (FAHP) merupakan gabungan metode AHP dengan pendekatan konsep fuzzy. FAHP menutupi kelemahan yang terdapat pada AHP, yaitu permasalahan yang mempunyai sifat subjektif. Ketidakpastian bilangan direpresentasikan dengan skala. Penentuan derajat keanggotaan FAHP yang dikembangkan oleh Chang (1996) menggunakan fungsi keanggotaan segitiga (Triangular Fuzzy Number/TFN). Fungsi keanggotaan segitiga merupakan gabungan antara dua garis (linear) [3]. Grafik fungsi keanggotaan segitiga digambarkan dalam bentuk kurva segitiga. 
Chang mendefinisikan nilai intensitas AHP ke dalam fuzzy segitiga yaitu membagi tiap himpunan fuzzy dengan dua, kecuali untuk intensitas kepentingan satu. Skala fuzzy segitiga yang digunakan Chang dapat dilihat pada Tabel 1.

Tabel 1 Skala nilai fuzzy segitiga [1]

\begin{tabular}{|c|c|c|c|}
\hline $\begin{array}{l}\text { Intensitas } \\
\text { Kepentingan } \\
\text { AHP }\end{array}$ & Himpunan Linguistik & $\begin{array}{l}\text { Triangular Fuzzy } \\
\text { Number (TFN) }\end{array}$ & $\begin{array}{l}\text { Reciprocal } \\
\text { (Kebalikan) }\end{array}$ \\
\hline 1 & $\begin{array}{l}\text { Perbandingan elemen yang sama } \\
\text { (Just Equal) }\end{array}$ & $(1, \mathbf{1}, 1)$ & $(1, \mathbf{1}, 1)$ \\
\hline 2 & Pertengahan (Intermediate) & $(1 / 2,1,3 / 2)$ & $(2 / 3, \mathbf{1}, 2)$ \\
\hline 3 & $\begin{array}{l}\begin{array}{l}\text { Elemen satu cukup } \\
\text { yang lainnya } \\
\text { important) }\end{array} \\
\text { (moderately }\end{array}$ & $(1, \mathbf{3} / \mathbf{2}, 2)$ & $(1 / 2,2 / 3,1)$ \\
\hline 4 & $\begin{array}{l}\text { Pertengahan (Intermediate) elemen } \\
\text { satu lebih cukup penting dari yang } \\
\text { lainnya) }\end{array}$ & $(3 / 2,2,5 / 2)$ & $(2 / 5,1 / 2,2 / 3)$ \\
\hline 5 & $\begin{array}{l}\text { Elemen satu kuat pentingnya dari } \\
\text { yang lain (Strongly Important) }\end{array}$ & $(2, \mathbf{5} / \mathbf{2}, 3)$ & $(1 / 3,2 / 5,1 / 2)$ \\
\hline 6 & Pertengahan (Intermediate) & $(5 / 2,3,7 / 2)$ & $(2 / 7, \mathbf{1 / 3}, 2 / 5)$ \\
\hline 7 & $\begin{array}{l}\text { Elemen satu lebih kuat pentingnya } \\
\text { dari yang lain (Very Strong) }\end{array}$ & $(3,7 / 2,4)$ & $(1 / 4,2 / 7,1 / 3)$ \\
\hline 8 & Pertengahan (Intermediate) & $(7 / 2,4,9 / 2)$ & $(2 / 9,1 / 4,2 / 7)$ \\
\hline 9 & $\begin{array}{l}\text { Elemen satu mutlak lebih penting } \\
\text { dari yang lainnya (Extremely } \\
\text { Strong) }\end{array}$ & $(4,9 / 2,9 / 2)$ & $(2 / 9,2 / 9,1 / 4)$ \\
\hline
\end{tabular}

\section{Langkah FAHP}

Langkah FAHP adalah sebagai berikut [1] :

1. Membuat struktur hierarki masalah yang akan diselesaikan dan menentukan perbandingan matriks berpasangan antar kriteria dengan skala TFN seperti pada Tabel 1.

Sebelum masuk ke penghitungan FAHP, struktur hierarki masalah diselesaikan terlebih dahulu dengan penghitungan AHP untuk menemukan konsistensi nilai matriks perbandingannya. Setelah nilai matriks perbandingn konsisten $(\mathrm{CR}<0.1)$, nilai matriks perbandingan AHP tersebut akan diubah menjadi nilai matriks perbandingan FAHP menggunakan Tabel 1. Sehingga dihasilkan matriks perbandingan FAHP seperti pada Tabel 2.
Tabel 2 Matriks perbandingan FAHP

\begin{tabular}{|l|lll|l|lll|}
\hline & \multicolumn{3}{|c|}{$\boldsymbol{M}_{\boldsymbol{j}}$} & $\ldots$ & \multicolumn{3}{c|}{$\boldsymbol{M}_{\boldsymbol{m}}$} \\
\hline & $l_{j}$ & $m_{j}$ & $u_{j}$ & $\ldots$ & $l_{m}$ & $m_{m}$ & $u_{m}$ \\
\hline $\boldsymbol{M}_{\boldsymbol{i}}$ & & & & $\ldots$ & & & \\
\hline$\cdot$ & & & & & & & \\
$\cdot$ & & & & $\cdots$ & & & \\
$\cdot$ & & & & & & & \\
\hline $\boldsymbol{M}_{\boldsymbol{m}}$ & & & & $\ldots$ & & & \\
\hline
\end{tabular}

2. Menentukan nilai sintesis fuzzy $\left(S_{i}\right)$ prioritas dengan rumus:

$$
S_{i}=\sum_{j=1}^{m} M_{g i}^{j} \otimes \frac{1}{\left[\sum_{i=1}^{n} \sum_{j=1}^{m} M_{g i}^{j}\right]} \ldots
$$

dengan:

$$
\begin{array}{ll}
S_{i} & =\text { nilai sintesis fuzzy } \\
\mathrm{M} & =\text { bilangan triangular fuzzy number }
\end{array}
$$




$$
\begin{array}{ll}
m & =\text { jumlah kriteria } \\
i & =\text { baris } \\
j & =\text { kolom } \\
g & =\text { parameter }(l, m, u)
\end{array}
$$

Untuk memperoleh $\sum_{j=1}^{m} M_{g i}^{j}$, yaitu dengan menggunakan penjumlahan fuzzy dari nilai $m$ pada sebuah matrik seperti di bawah ini.

$\sum_{j=1}^{m} M_{g i}^{j}=\left(\sum_{j=1}^{m} l_{j}, \sum_{j=1}^{m} m_{j}, \sum_{j=1}^{m} u_{j}\right)$.

Untuk memperoleh $\frac{1}{\left[\sum_{i=1}^{n} \sum_{j=1}^{m} M_{g i}^{j}\right]}$, dilakukan operasi penjumlahan fuzzy dari $M_{g i}^{j}(j=$ $1,2, \ldots, m)$ dalam matriks keputusan $(n \times m)$, sebagai berikut:

$\frac{1}{\left[\sum_{i=1}^{n} \sum_{j=1}^{m} M_{g i}^{j}\right]}=\left(\frac{1}{\sum_{i=1}^{n} u_{i}}, \frac{1}{\sum_{i=1}^{n} m_{i}}, \frac{1}{\sum_{i=1}^{n} l_{i}}\right)$

Matriks perbandingan nilai $S_{i}$ dapat dilihat pada Tabel 2.3.

3. Menentukan nilai vektor $(V)$. Jika hasil yang diperoleh pada setiap matrik fuzzy, $M_{2}=\left(l_{2}, m_{2}, u_{2}\right) \geq M_{1}=\left(l_{1}, m_{1}, u_{1}\right)$ dapat didefinisikan sebagai nilai vektor.

$V\left(M_{2} \geq M_{1}\right)=\sup \left[\min \left(\mu M_{1}(x)\right), \min \left(\mu M_{2}(y)\right)\right] \ldots$

$V\left(M_{2} \geq M_{1}\right)=\left\{\begin{array}{c}1 ; \quad m_{2} \geq m_{1} \\ 0 ; \quad l_{1} \geq u_{2} \\ \frac{l_{1}-u_{2}}{\left(m_{2}-u_{2}\right)-\left(m_{1}-l_{1}\right)} ; \text { selain diatas }\end{array}\right.$

4. Menentukan nilai ordinat $\left(d^{\prime}\right)$. Jika hasil nilai fuzzy lebih besar dari k dimana $M_{i}(\mathrm{i}=1,2, . ., \mathrm{k})$ yang dapat didefinisikan sebagai berikut:

$$
\begin{aligned}
V\left(M \geq M_{1}, M_{2}, \ldots, M_{k}\right) & =V\left[\begin{array}{c}
\left(M \geq M_{1}\right) \text { dan } \\
\left(M \geq M_{2}\right) \text { dan } \ldots\left(M \geq M_{i}\right)
\end{array}\right] \\
& =\min V\left(M \geq M_{i}\right) \ldots \ldots(6)
\end{aligned}
$$

dengan:

$$
\begin{aligned}
V & =\text { nilai vektor } \\
M & =\text { Matriks nilai sintesis fuzzy } \\
i & =1,2,3, \ldots k
\end{aligned}
$$

Sehingga diperoleh nilai ordinat (d')

$d^{\prime}\left(A_{i}\right)=\min V\left(S_{i} \geq S_{k}\right)$

dengan:

$S_{i} \quad=$ nilai sintesis fuzzy satu

$S_{k} \quad=$ nilai sintesis fuzzy yang lainnya

Untuk $k=1,2, \ldots, \mathrm{n} ; k \neq i$, maka diperoleh nilai vektor:

$W^{\prime}=\left(d^{\prime}\left(A_{1}\right), d^{\prime}\left(A_{2}\right), \ldots, d^{\prime}\left(A_{i}\right)\right)^{T}$

dengan $A_{i}(i=1,2, \ldots, n)$ adalah $\mathrm{n}$ elemen keputusan dan $d^{\prime}(A i)$ adalah nilai yang menggambarkan pilihan relatif masingmasing atribut keputusan.

5. Normalisasi nilai bobot vektor fuzzy $(W)$ Normalisasi nilai bobot vektor diperoleh dengan persamaan :

$d\left(A_{n}\right)=\frac{d^{\prime}\left(A_{n}\right)}{\sum_{i=1}^{n} d^{\prime}\left(A_{n}\right)}$

Sehingga didapatkan nilai normalisasi bobot vector fuzzy adalah :

$W=\left(d\left(A_{1}\right), d\left(A_{2}\right), \ldots, d\left(A_{n}\right)\right)^{T}$

dengan $W$ adalah bilangan non fuzzy.

Tabel 3 Matriks perbandingan nilai $S_{i}$

\begin{tabular}{|c|c|c|c|c|c|c|}
\hline & \multicolumn{4}{|c|}{$\sum_{j=1}^{m} M_{g i}^{j}$} & \multicolumn{2}{c|}{$S_{i}$} \\
\hline$M_{\boldsymbol{i}}$ & $\sum_{j=1}^{m} l_{j}$ & $\sum_{j=1}^{m} m_{j}$ & $\sum_{j=1}^{m} u_{j}$ & $S_{i}$ & & \\
\hline$\cdot$ & $\cdot$ & $\cdot$ & $\cdot$ & $\cdot$ & & \\
\hline $\boldsymbol{M}_{\boldsymbol{m}}$ & $\sum_{j=m}^{m} l_{j}$ & $\sum_{j=m}^{m} m_{j}$ & $\sum_{j=m}^{m} u_{j}$ & $S_{m}$ & & \\
\hline$\left[\sum_{i=1}^{n} \sum_{j=1}^{m} M_{g i}^{j}\right]$ & $\sum_{i=1}^{n} u_{i}$ & $\sum_{i=1}^{n} m_{i}$ & $\sum_{i=1}^{n} l_{i}$ & & \\
\hline
\end{tabular}


Tiap elemen bobot vektor dibagi jumlah bobot vektor itu sendiri. Jumlah bobot yang telah dinormalisasi akan bernilai 1 . Normalisasi nilai bobot vektor fuzzy kriteria sama dengan nilai bobot prioritas global (yang menjadi tujuannya). Normalisasi bobot ini akan dilakukan agar nilai dalam vektor diperbolehkan menjadi analog bobot dan terdiri dari bilangan yang non-fuzzy.

\section{ANALISIS DAN PERANCANGAN Analisis Penentuan Lokasi Hotel dengan Metode FAHP}

Pada bagian ini akan dilakukan analisis perhitungan menggunakan metode FAHP. Analisis ini dilakukan dengan mengambil contoh kasus seperti pada contoh 1. Hierarki SPK pemilihan Hotel dapat dilihat pada Gambar 1.

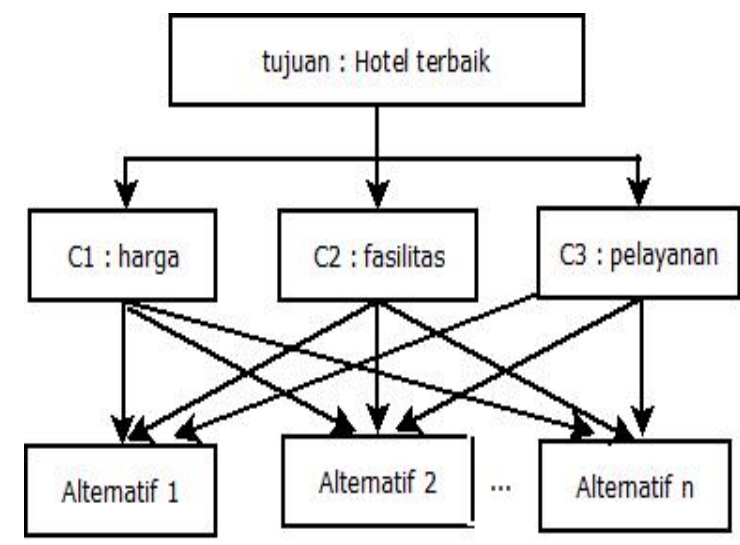

Gambar 1. Hierarki SPK HOTEL

Contoh kasus :

Seorang pengguna ingin mencari hotel dengan harga yang diinginkan per malam adalah $\mathrm{Rp} 800.000,00$. Lokasi yang diinginkan adalah yang memiliki latitude -7.0144233 dan longitude 110.43437389999997. Fasilitas yang diinginkan adalah parkir, restoran, ruang santai, ruang rokok, coffee shop, dan gym. Sedangkan pelayanan yang diinginkan adalah komunikasi, front office, concierge, dan tata graha. Hotel manakah yang sesuai bagi pengguna?

Pembahasan kasus :

Langkah dalam menggunakan metode FAHP adalah sebagai berikut :
Setelah pengunjung mengisi seluruh data pada form spk, maka didapatkan data seperti pada Tabel 4.

Tabel 4. Data masukan pengunjung

\begin{tabular}{|l|l|}
\hline \multicolumn{1}{|c|}{ Kriteria } & \multicolumn{1}{|c|}{ Data yang dimasukkan } \\
\hline Harga & 800.000 \\
\hline Fasilitas & $\begin{array}{l}\text { parkir, restoran, ruang santai, } \\
\text { ruang rokok, coffee shop, dan } \\
\text { gym }\end{array}$ \\
\hline Pelayanan & $\begin{array}{l}\text { komunikasi, front office, } \\
\text { concierge, dan tata graha }\end{array}$ \\
\hline
\end{tabular}

Data latitude dan longitude yang dimasukkan oleh pengunjung digunakan untul menghitung jarak antara lokasi hotel yang diinginkan dengan lokasi hotel pada database. Kemudian diambil 3 hotel dengan jarak yang paling dekat dengan lokasi yang diinginkan. Sehingga didapat 3 hotel dengan jarak terdekat seperti pada Tabel 5.

Sebelum masuk ke penghitungan FAHP, struktur hirarki masalah diselesaikan terlebih dahulu dengan penghitungan AHP untuk menemukan konsistensi nilai matriks perbandingannya.

1. Menentukan kriteria yang dijadikan acuan dalam pengambilan keputusan
a. $C_{1}$ adalah harga yang diinginkan
b. $C_{2}$ adalah fasilitas yang diinginkan
c. $C_{3}$ adalah pelayanan yang diinginkan

2. Menentukan nilai konversi untuk tiap kriteria

Tabel konversi nilai digunakan untuk mengubah harga yang diinginkan menjadi nilai dengan range 1 hingga 9. Tabel konversi harga dapat dilihat pada Tabel 6. Sedangkan tabel konversi fasilitas dapat dilihat pada Tabel 7, dan tabel konversi pelayanan dapat dilihat pada Tabel 8 . 
Tabel 5. Data hotel terdekat

\begin{tabular}{|c|c|l|l|c|}
\hline Nama Hotel & Harga & \multicolumn{1}{c|}{ Fasilitas } & \multicolumn{1}{|c|}{ Pelayanan } & Jarak $(\mathrm{km})$ \\
\hline Grand Candi & 700.000 & $\begin{array}{l}\text { Parkir, restoran, ruang } \\
\text { santai, ruang rokok, } \\
\text { coffee shop, gym, kolam } \\
\text { renang, wifi. }\end{array}$ & $\begin{array}{l}\text { Komunikasi, Front office, } \\
\text { concierge, tata graha, } \\
\text { laundry, room service, } \\
\text { security, antar jemput, } \\
\text { kesehatan. }\end{array}$ & 0.937 \\
\hline Patrajasa & 550.000 & $\begin{array}{l}\text { Parkir, restoran, ruang } \\
\text { santai, coffee shop, spa, } \\
\text { kolam renang, wifi. }\end{array}$ & $\begin{array}{l}\text { Komunikasi, Front office, } \\
\text { concierge, tata graha, } \\
\text { laundry, room service, } \\
\text { security. }\end{array}$ & 1.29 \\
\hline Permata & 184.000 & Parkir, ruang santai. & $\begin{array}{l}\text { Komunikasi, Front office, } \\
\text { concierge, laundry, room } \\
\text { service, security, antar } \\
\text { jemput. }\end{array}$ & 1.425 \\
\hline
\end{tabular}

Tabel 6. Konversi harga

\begin{tabular}{|l|c|}
\hline \multicolumn{1}{|c|}{ Harga } & Nilai \\
\hline Kurang dari 100.000 & 9 \\
\hline $100.001-500.000$ & 8 \\
\hline $500.001-1.000 .000$ & 7 \\
\hline $1.000 .001-1.500 .000$ & 6 \\
\hline $1.500 .001-2.000 .000$ & 5 \\
\hline $2.000 .001-2.500 .000$ & 4 \\
\hline $2.500 .001-3.000 .000$ & 3 \\
\hline $3.000 .001-3.500 .000$ & 2 \\
\hline Lebih dari 3.500 .000 & 1 \\
\hline
\end{tabular}

Tabel 7. konversi fasilitas

\begin{tabular}{|l|c|}
\hline \multicolumn{1}{|c|}{ Fasilitas } & Nilai \\
\hline Sesuai & 9 \\
\hline Kurang 1 fasilitas & 8 \\
\hline Kurang 2 fasilitas & 7 \\
\hline Kurang 3 fasilitas & 6 \\
\hline Kurang 4 fasilitas & 5 \\
\hline Kurang 5 fasilitas & 4 \\
\hline Kurang 6 fasilitas & 3 \\
\hline Kurang 7 fasilitas & 2 \\
\hline Kurang 8 fasilitas & 1 \\
\hline
\end{tabular}

Tabel 8. konversi pelayanan

\begin{tabular}{|l|c|}
\hline \multicolumn{1}{|c|}{ Pelayanan } & Nilai \\
\hline Sesuai & 9 \\
\hline Kurang 1 pelayanan & 8 \\
\hline Kurang 2 pelayanan & 7 \\
\hline Kurang 3 pelayanan & 6 \\
\hline Kurang 4 pelayanan & 5 \\
\hline Kurang 5 pelayanan & 4 \\
\hline Kurang 6 pelayanan & 3 \\
\hline Kurang 7 pelayanan & 2 \\
\hline Kurang 8 pelayanan & 1 \\
\hline
\end{tabular}

Setelah dilakukan konversi harga, fasilitas, dan pelayanan, maka hasil konversi data kriteria dapat dilihat pada Tabel 9 dan hasil konversi data hotel dapat dilihat pada Tabel 10.

Tabel 9. Hasil konversi data kriteria

\begin{tabular}{|l|c|}
\hline \multicolumn{1}{|c|}{ Kriteria } & Nilai \\
\hline Harga & 7 \\
\hline Fasilitas & 6 \\
\hline Pelayanan & 4 \\
\hline
\end{tabular}


Tabel 10. Hasil konversi data hotel

\begin{tabular}{|l|c|c|c|c|}
\hline \multicolumn{1}{|c|}{ Nama Hotel } & Harga & Fasilitas & Pelayanan & Jarak $(\mathrm{km})$ \\
\hline Grand Candi & 7 & 8 & 9 & 8 \\
\hline Patrajasa & 7 & 7 & 7 & 8 \\
\hline Permata & 8 & 2 & 7 & 8 \\
\hline
\end{tabular}

3. Menentukan matriks perbandingan AHP Matriks perbandingan AHP kriteria didapat langsung tanpa membandingkan tiap nilai kriteria satu per satu. Nilai untuk matriks perbandingan dihitung berdasarkan jarak antar nilai kriteria yang didapat dari Tabel 3.6. Matriks perbandingan AHP dapat dilihat pada Tabel 11.

Tabel 11 Matriks perbandingan AHP kriteria

\begin{tabular}{|c|l|l|l|}
\hline & \multicolumn{1}{|c|}{$\boldsymbol{C}_{\mathbf{1}}$} & \multicolumn{1}{|c|}{$\boldsymbol{C}_{\mathbf{2}}$} & $\boldsymbol{C}_{\mathbf{3}}$ \\
\hline $\boldsymbol{C}_{\mathbf{1}}$ & 1 & 2 & 4 \\
\hline $\boldsymbol{C}_{\mathbf{2}}$ & $1 / 2$ & 1 & 3 \\
\hline $\boldsymbol{C}_{\mathbf{3}}$ & $1 / 4$ & $1 / 3$ & 1 \\
\hline Jumlah & 1.75 & 3.33 & 8 \\
\hline
\end{tabular}

Nilai inputan perbandingan matriks di atas kemudian diproses untuk mencari bobot vektor prioritas, lamda, CI, dan CR. Sebelum menghitung nilai bobot prioritas, setiap sel pada kolom matriks dibagi dengan jumlah kolom pada tiap selnya.

Untuk kolom pertama :

$C_{1}=\frac{1}{1.75}=0.57$

$C_{2}=\frac{1 / 2}{1.75}=0.29$

$C_{3}=\frac{1 / 4}{1.75}=0.14$, begitu seterusnya untuk kolom ke-2 dan ke-3.

Menghitung nilai bobot prioritas yaitu untuk hasil pembagian sel yang telah diperoleh pada setiap baris matriks dijumlahkan, kemudian dibagi dengan banyaknya sel pada baris tersebut (banyak kriteria $=3$ ). Kesimpulan bobot prioritas kriteria dapat dilihat pada Tabel 3.9 .

Menghitung matriks penjumlahan tiap baris, yaitu dengan mengalikan nilai prioritas pada Tabel 12 dengan tiap nilai pada matriks perbandingan berpasangan pada Tabel 11 sehingga didapatkan hasil seperti pada Tabel 13.

Tabel 12 Kesimpulan bobot prioritas kriteria

\begin{tabular}{|l|l|l|l|l|}
\hline & \multicolumn{1}{|c|}{$\boldsymbol{C}_{\mathbf{1}}$} & \multicolumn{1}{|c|}{$\boldsymbol{C}_{\mathbf{2}}$} & \multicolumn{1}{c|}{$\boldsymbol{C}_{\mathbf{3}}$} & \multicolumn{1}{c|}{ Bobot Prioritas (Eigenvector) } \\
\hline $\boldsymbol{C}_{\boldsymbol{1}}$ & 0.57 & 0.60 & 0.50 & $=\frac{0.57+0.60+0.50}{3}=0.56$ \\
\hline $\boldsymbol{C}_{\mathbf{2}}$ & 0.29 & 0.30 & 0.38 & $=\frac{0.29+0.30+0.38}{3}=0.32$ \\
\hline $\boldsymbol{C}_{\mathbf{3}}$ & 0.14 & 0.09 & 0.13 & $=\frac{0.14+0.09+0.13}{3}=0.12$ \\
\hline \multicolumn{2}{|l|}{ Jumlah } & 1 \\
\hline
\end{tabular}


Tabel 13. Matriks penjumlahan tiap baris

\begin{tabular}{|l|c|c|c|c|}
\hline & $\boldsymbol{C}_{\mathbf{1}}$ & $\boldsymbol{C}_{\mathbf{2}}$ & $\boldsymbol{C}_{\mathbf{3}}$ & Jumlah \\
\hline $\boldsymbol{C}_{\boldsymbol{1}}$ & 0.56 & 0.64 & 0.48 & 1.68 \\
\hline $\boldsymbol{C}_{\mathbf{2}}$ & 0.28 & 0.32 & 0.36 & 0.96 \\
\hline $\boldsymbol{C}_{\mathbf{3}}$ & 0.14 & 0.11 & 0.12 & 0.12 \\
\hline
\end{tabular}

Kemudian bobot prioritas dari Tabel 12 dan jumlah dari Tabel 13 dijumlahkan seperti pada tabel 14.

Tabel 14 Matriks penjumlahan

\begin{tabular}{|l|c|c|c|}
\hline & Jumlah & $\begin{array}{c}\text { Bobot } \\
\text { Prioritas }\end{array}$ & Hasil \\
\hline $\boldsymbol{C}_{\mathbf{1}}$ & 1.68 & 0.56 & 2.24 \\
\hline $\boldsymbol{C}_{\mathbf{2}}$ & 0.96 & 0.32 & 1.28 \\
\hline $\boldsymbol{C}_{\mathbf{3}}$ & 0.37 & 0.12 & 0.49 \\
\hline \multicolumn{3}{|c|}{ Total } & 4.01 \\
\hline
\end{tabular}

Menghitung nilai lamda dan menghitung nilai CI dan CR.

$$
\begin{aligned}
\lambda \text { maks } & =4.01 / 3=1.34 \\
\mathrm{CI} \quad= & \frac{1.34-3}{2} \\
= & -0.83(n=3, R I=0.58)
\end{aligned}
$$

$$
\begin{aligned}
\mathrm{CR} \quad & =\frac{-0.83}{0.58} \\
& =-1.43(\text { Konsisten } \rightarrow \text { Karena }<0.1)
\end{aligned}
$$

4. Menentukan Matriks Perbandingan FAHP

Konversi nilai perbandingan AHP ke nilai himpunan fuzzy (F-AHP) dilakukan dengan menggunakan TFN pada Tabel 1.

Proses konversi nilai perbandingan AHP menjadi nilai himpunan FAHP:

a. $C_{1}$ terhadap $C_{1}: 1$

TFN : $(1,1,1)$, maka $l_{1}=1 ; m_{1}=1 ; u_{1}=$ 1.

b. $\quad C_{1}$ terhadap $C_{2}: 2$

TFN : $(1 / 2,1,3 / 2)$, maka $l_{2}=1 / 2 ; m_{2}=1$; $u_{2}=3 / 2$.

c. $C_{1}$ terhadap $C_{3}: 4$

TFN : $(3 / 2,2,5 / 2)$, maka $l_{3}=3 / 2 ; m_{3}=2$; $u_{3}=5 / 2$.

Proses konversi dilakukan hingga didapatkan semua nilai FAHP untuk tiap kriteria. Adapun hasil konversi nilai perbandingan matriksnya dapat dilihat pada Tabel 15.

5. Menentukan nilai sintesis fuzzy (Si) prioritas

\begin{tabular}{|c|c|c|c|c|c|c|c|c|c|}
\hline & \multicolumn{3}{|c|}{$C_{1}$} & \multicolumn{3}{|c|}{$C_{2}$} & \multicolumn{3}{|c|}{$C_{3}$} \\
\hline & $l_{1}$ & $m_{1}$ & $u_{1}$ & $l_{2}$ & $m_{2}$ & $u_{2}$ & $l_{3}$ & $m_{3}$ & $u_{3}$ \\
\hline$C_{1}$ & 1 & 1 & 1 & 0.5 & 1 & 1.5 & 1.5 & 2 & 2.5 \\
\hline$C_{2}$ & 0.67 & 1 & 2 & 1 & 1 & 1 & 1 & 1.5 & 2 \\
\hline$C_{3}$ & 0.4 & 0.5 & 0.67 & 0.5 & 0.67 & 1 & 1 & 1 & 1 \\
\hline
\end{tabular}
dengan persamaan rumus (2.7).

Hasil pengolahan table 15, dapat diperoleh nilai sintesis seperti Tabel 16.

Tabel 3.12 Matriks perbandingan FAHP kriteria 
Tabel 16 Nilai sintesis fuzzy (Si)

\begin{tabular}{|c|l|l|l|l|l|l|l|}
\hline & \multicolumn{5}{|c|}{$\sum_{j=1}^{m} M_{g i}^{j}$} & \multicolumn{5}{c|}{$S_{i}$} \\
\hline$C_{1}$ & 3 & 4 & 5 & $S_{1}$ & 0.24 & 0.41 & 0.66 \\
\hline$C_{2}$ & 2.67 & 3.5 & 5 & $S_{2}$ & 0.21 & 0.36 & 0.66 \\
\hline$C_{3}$ & 1.9 & 2.17 & 2.67 & $S_{3}$ & 0.15 & 0.22 & 0.35 \\
\hline$\left[\sum_{i=1}^{n} \sum_{j=1}^{m} M_{g i}^{j}\right]$ & 7.57 & 9.67 & 12.67 & & & & \\
\end{tabular}

Perhitungan $S_{i}$ :

1. Perhitungan $S_{i}$ untuk $C_{1}$

$$
\begin{aligned}
S_{1} & =(3 ; 4 ; 5) \otimes\left(\frac{1}{12.67} ; \frac{1}{9.67} ; \frac{1}{7.57}\right) \\
& =(3 ; 4 ; 5) \otimes(0.08 ; 0.10 ; 0.13) \\
& =0.24 ; 0.41 ; 0.66
\end{aligned}
$$

2. Perhitungan $S_{i}$ untuk $C_{2}$

$$
\begin{aligned}
S_{2} & =(2.67 ; 3.5 ; 5) \bigotimes(0.08 ; 0.10 ; 0.13) \\
& =0.21 ; 0.36 ; 0.66
\end{aligned}
$$

3. Perhitungan $S_{i}$ untuk $C_{3}$

$$
\begin{aligned}
& S_{3}=(1.9 ; 2.17 ; 2.67) \otimes(0.08 ; 0.10 ; \\
& 0.13) \\
& \quad=0.15 ; 0.22 ; 0.35
\end{aligned}
$$

6. Jika telah didapat nilai $S_{i}$, maka dapat didefinisikan sebagai nilai vector (V) dengan menggunakan persamaan rumus (2.5).

a. $V$ untuk $C_{1}$

1. $V$ untuk $C_{1}$ terhadap $C_{2}$

$m_{1}=0.41 ; m_{2}=0.36 ; l_{1}=0.24 ; u_{2}=$ 0.66

$m_{2} \leq m_{1}$ dan $l_{1} \leq u_{2}$

Sehingga $V\left(M_{2} \geq M_{1}\right)=$

$$
\begin{array}{ll}
\frac{l_{1}-u_{2}}{\left(m_{2}-u_{2}\right)-\left(m_{1}-l_{1}\right)} & = \\
\frac{0.24-0.66}{(0.36-0.66)-(0.41-0.24)} & =0.89
\end{array}
$$

2. $V$ untuk $C_{1}$ terhadap $C_{3}$

$$
\begin{aligned}
& m_{1}=0.41 ; m_{3}=0.22 ; l_{1}=0.24 ; u_{3}= \\
& 0.35 \\
& m_{3} \leq m_{1} \text { dan } l_{1} \leq u_{3} \\
& \text { Sehingga } V\left(M_{2} \geq M_{1}\right) \\
& =\frac{0.24-0.35}{(0.22-0.35)-(0.41-0.24)}=0.38
\end{aligned}
$$

Begitu seterusnya hingga didapat $V$ untuk $C_{2}$ dan $V$ untuk $C_{3}$.
7. Normalisasi bobot vector $(W)$ atau bobot prioritas kriteria yang telah diperoleh dengan persamaan rumus (2.8) dan (2.9), sehingga $W$ :

$W=(0.201,0.27,0.53)^{T}$

Diperoleh bobot prioritas kriteria yaitu $0.201,0.27,0.53$.

Langkah menghitung bobot F-AHP alternatif dapat dihitung dari hasil konversi data hotel yang terdapat pada Tabel 3.7 dengan cara yang sama dengan menghitung kriteria seperti langkah di atas. Sehingga didapat matriks perbandingan alternatif untuk tiap kriteria seperti pada Tabel 17.

Tabel 17 Matriks perbandingan alternatif terhadap tiap kriteria

\begin{tabular}{|c|l|l|l|}
\hline Terhadap & \multicolumn{1}{|c|}{$\boldsymbol{A}_{\mathbf{1}}$} & \multicolumn{1}{|c|}{$\boldsymbol{A}_{\mathbf{2}}$} & \multicolumn{1}{c|}{$\boldsymbol{A}_{\mathbf{3}}$} \\
\hline $\boldsymbol{C}_{\mathbf{1}}$ & 0.33 & 0.33 & 0.33 \\
\hline $\boldsymbol{C}_{\mathbf{2}}$ & 0 & 0 & 0 \\
\hline $\boldsymbol{C}_{\mathbf{3}}$ & 0.71 & 0.41 & 0.41 \\
\hline
\end{tabular}

Setelah didapat nilai matriks perbandingan alternatif terhadap tiap kriteria, kemudian dapat dihitung bobot akhirnya seperti pada Tabel 18 . Bobot akhir dihitung dengan menjumlahkan hasil perkalian tiap nilai alternatif terhadap nilai kriteria.

Tabel 18 Perhitungan bobot akhir:

\begin{tabular}{|l|l|l|l|l|}
\hline & $\boldsymbol{C}_{\mathbf{1}}$ & $\boldsymbol{C}_{\mathbf{2}}$ & $\boldsymbol{C}_{\mathbf{3}}$ & Bobot \\
\hline & 0.201 & 0.27 & 0.53 & 1 \\
\hline $\boldsymbol{A}_{\mathbf{1}}$ & 0.33 & 0 & 0.71 & 0.29 \\
\hline $\boldsymbol{A}_{\mathbf{2}}$ & 0.33 & 0 & 0.41 & 0.29 \\
\hline $\boldsymbol{A}_{\mathbf{3}}$ & 0.33 & 0 & 0.41 & 0.16 \\
\hline
\end{tabular}


Perhitungan bobot akhir

$$
\begin{aligned}
& \boldsymbol{A}_{\mathbf{1}}=(0.33 \times 0.201)+(0 \times 0.27)+(0.71 \times \\
& 0.53) \\
& =0.29
\end{aligned}
$$

Sehingga didapatkan alternatif terbaik adalah alternatif dengan bobot akhir tertinggi, yaitu $A_{1}$ dan $A_{2}$ dengan bobot sebesar 0.29.

ERD pada sistem diilustrasikan pada Gambar 2.

\section{Data Context Diagram (DCD)}

DCD untuk sistem dapat dilihat pada Gambar 3. Seluruh external entity akan mengakses satu SPK Pemilihan Hotel. External Entity tersebut adalah pengunjung dan admin.

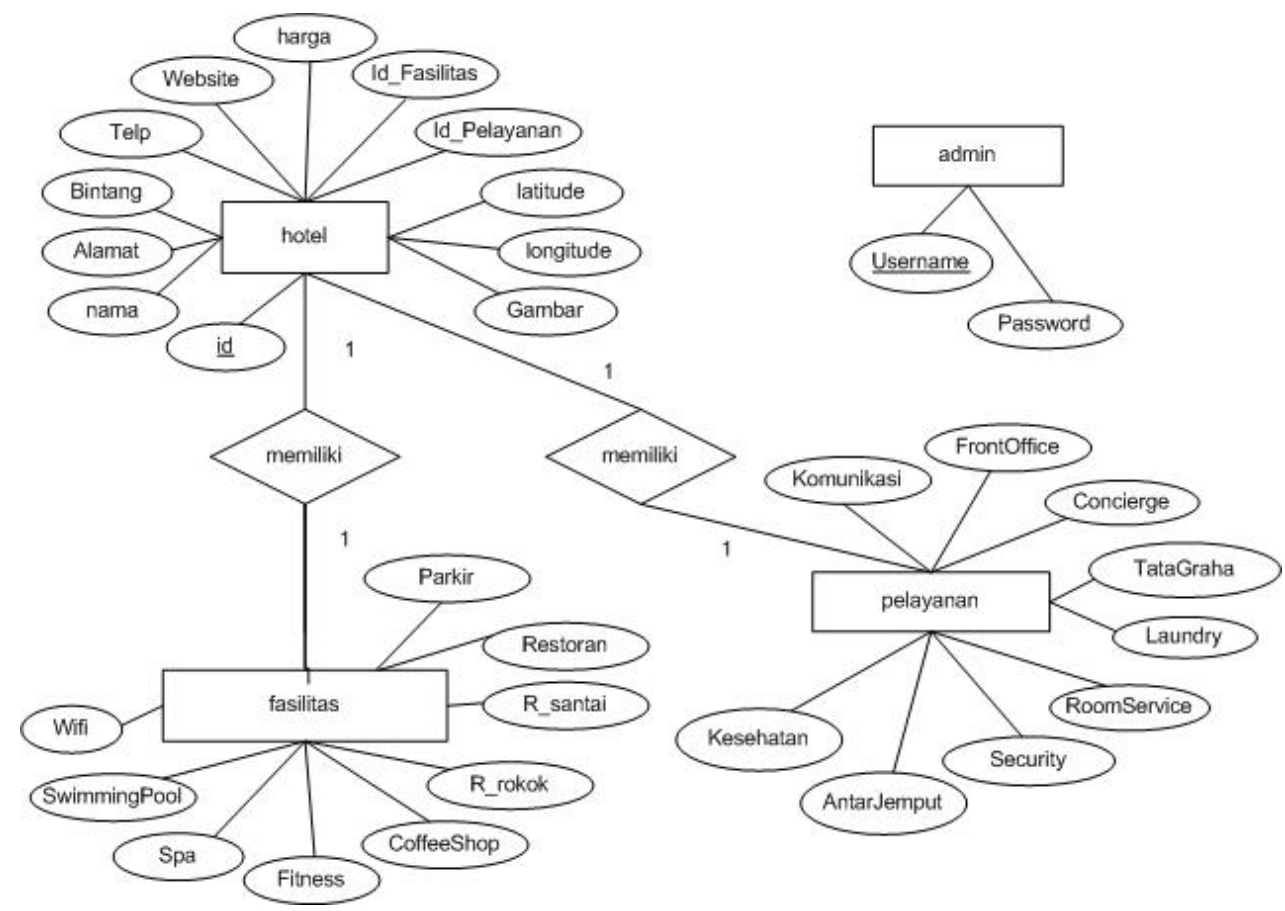

Gambar 2. Entity Relationship Diagram

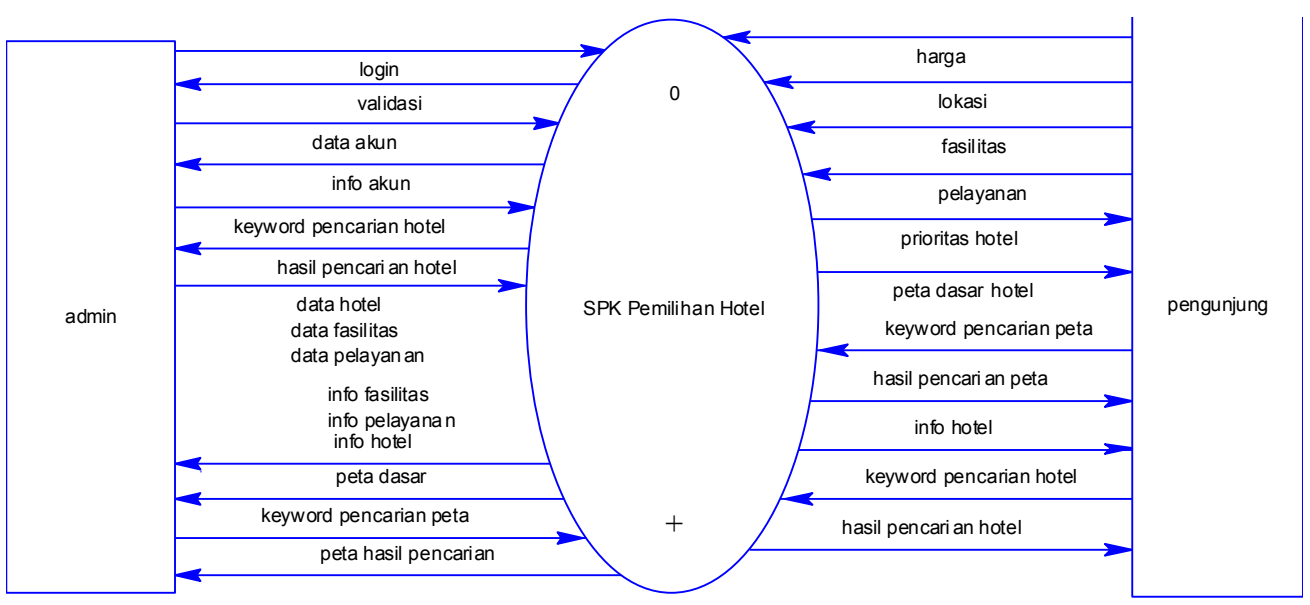

Gambar.3. Data Context Diagram 


\section{IMPLEMENTASI DAN PENGUJIAN}

Implementasi antarmuka merupakan hasil transformasi perancangan antarmuka menjadi tampilan pada SPK HOTEL. Struktur menu SPK Hotel dapat dilihat pada Gambar 4. Halaman utama SPK HOTEL dapat dilihat pada Gambar 4.

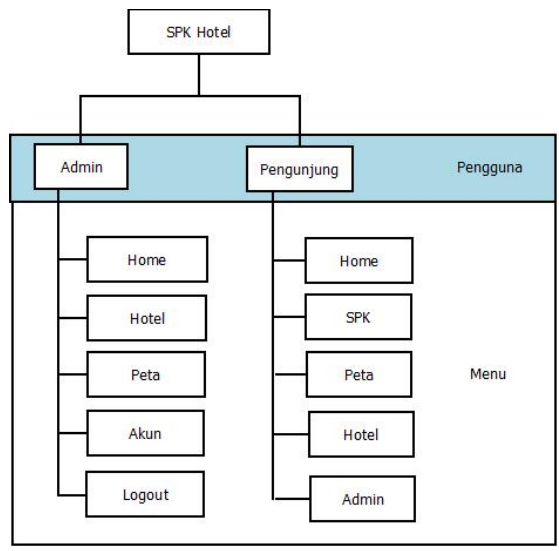

Gambar 4. Struktur Menu

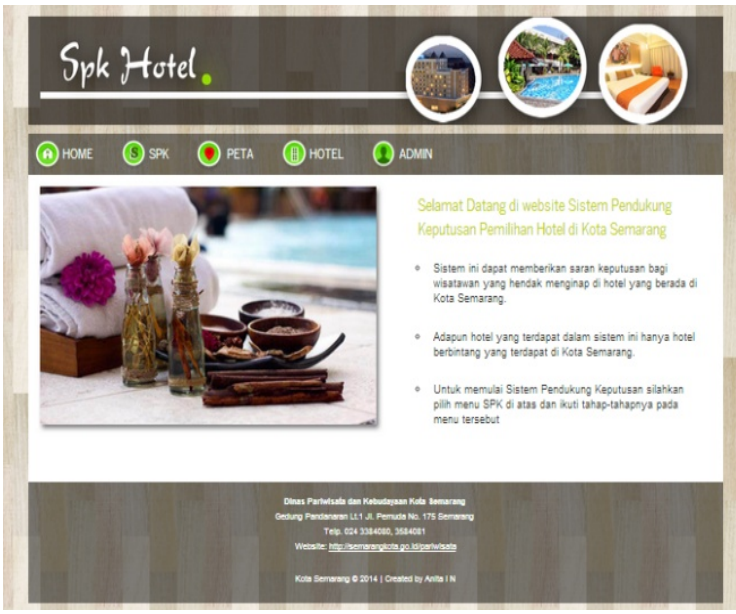

Gambar 5 Halaman Utama SPK HOTEL

Menu SPK digunakan oleh pengunjung untuk membantu pemilihan hotel. Menu SPK akan menampilkan form yang harus diisi datanya oleh pengunjung, yaitu harga, fasilitas, pelayanan, dan lokasi yang diinginkan. Halaman SPK dapat dilihat pada Gambar 6. Setelah pengunjung menekan tombol 'Lihat Hasil', maka akan muncul Halaman Hasil Perangkingan Hotel seperti pada Gambar 7.

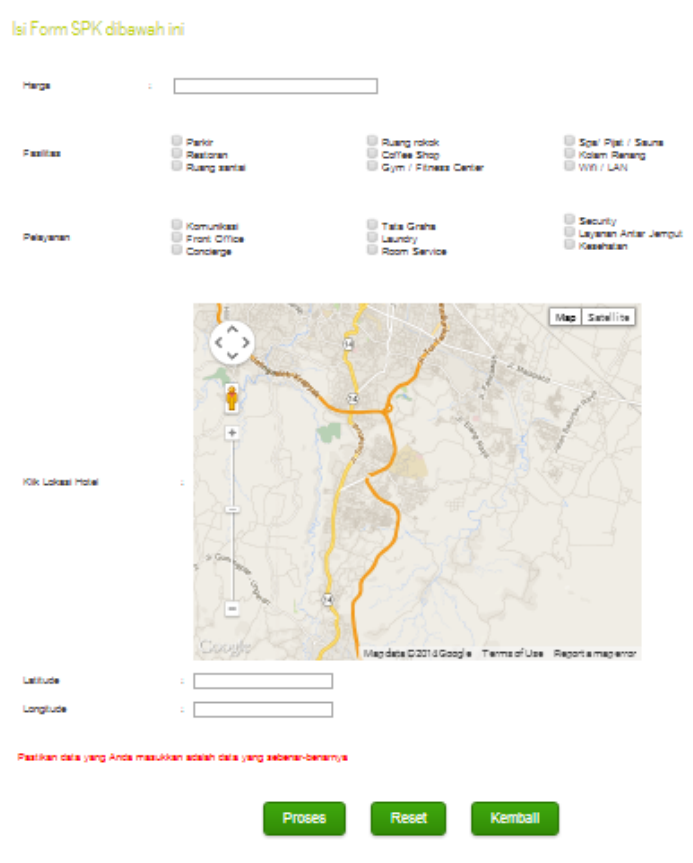

Gambar 6 Menu SPK

Hasil Perangkingan Hotel

\begin{tabular}{||c|c||c||}
\hline Nama Hotel & Bobot & Presentase \\
\hline Hotel patra jasa & 0.267814087948 & $36 \%$ \\
\hline Hotel Permata & 0.287814087948 & $38 \%$ \\
\hline Hotel Grand Candi & 0.202982308443 & $27 \%$ \\
\hline
\end{tabular}

Lihat Peta

Kembali ke Halaman SPK

Gambar 7 Form Hasil Perangkingan Hotel

\section{Hasil Pengujian}

Pengujian yang telah dilakukan terhadap Sistem Pendukung Keputusan Pemilihan Hotel di Kota Semarang dengan Metode FAHP ini memperoleh hasil pengujian dengan perhitungan dari sistem, dan perhitungan manual yang dapat dilihat pada Contoh 1. Data pengujian diperoleh melalui data hotel dari Dinas Pariwisata dan Kebudayaan Kota Semarang. Tabel hasil pengujian dengan Perhitungan Sistem dan Perhitungan Manual dapat dilihat pada tabel 19. 
Tabel 19. Hasil pengujian

\begin{tabular}{|c|c|c|c|c|c|c|c|}
\hline \multirow[t]{2}{*}{ No } & \multicolumn{5}{|c|}{ Data Masukan } & \multicolumn{2}{|l|}{ Hasil Keluaran } \\
\hline & Harga & $\begin{array}{l}\text { Fasi } \\
\text { litas }\end{array}$ & $\begin{array}{l}\text { Pelay } \\
\text { anan }\end{array}$ & Latitude & $\begin{array}{l}\text { Longitu } \\
\text { de }\end{array}$ & Sistem & Manual \\
\hline 1. & 100000 & 4 & 2 & $\begin{array}{l}- \\
6.9938421\end{array}$ & $\begin{array}{l}110.411 \\
381\end{array}$ & $\begin{array}{lll}\text { Hotel Merbabu } & \text { : } \\
0.394174750197 & \\
\text { Hotel Ciputra } & \text { : } \\
0.0985436875493 & \\
\text { Hotel Horison } & : \\
0.0985436875493 & \end{array}$ & $\begin{array}{l}\text { Hotel Merbabu : } \\
0.395 \\
\text { Hotel Ciputra : } \\
0.099 \\
\text { Hotel Horison : } \\
0.097\end{array}$ \\
\hline 2. & 210000 & 5 & 2 & $\begin{array}{l}- \\
6.9853619 \\
99999999\end{array}$ & $\begin{array}{l}110.441 \\
5521999 \\
9993\end{array}$ & $\begin{array}{l}\text { Hotel Siliwangi : } \\
0.333333333333 \\
\text { Hotel Merbabu : } \\
0.333333333333 \\
\text { Hotel Nyata Plasa : } \\
0.333333333333\end{array}$ & $\begin{array}{l}\text { Hotel Siliwangi } \\
: 0.333 \\
\text { Hotel Merbabu : } \\
0.333 \\
\text { Hotel Nyata } \\
\text { Plasa : } 0.333\end{array}$ \\
\hline 3. & 300000 & 3 & 4 & $\begin{array}{l}- \\
6.9903413\end{array}$ & $\begin{array}{l}110.396 \\
1042999 \\
9993\end{array}$ & $\begin{array}{lll}\text { Hotel merbabu } & \text { : } \\
0.420544668477 & \\
\text { Hotel Ciputra } & \text { : } \\
0.420544668477 & \\
\text { Hotel Siliwangi : } & 0 . \\
186840239909 & \\
\end{array}$ & $\begin{array}{l}\text { Hotel merbabu : } \\
0.421 \\
\text { Hotel Ciputra : } \\
0.420 \\
\text { Hotel Siliwangi } \\
: 0.187\end{array}$ \\
\hline 4. & 670000 & 8 & 6 & $\begin{array}{l}- \\
6.9774740 \\
99999999\end{array}$ & $\begin{array}{l}110.420 \\
7361\end{array}$ & $\begin{array}{lr}\text { Hotel merbabu } \\
0.436303316332 \\
\text { Hotel ciputra } \\
0.236532881671 \\
\text { Hotel metro } \\
0.236532881671\end{array}$ & $\begin{array}{l}\text { Hotel merbabu : } \\
0.436 \\
\text { Hotel ciputra : } \\
0.237 \\
\text { Hotel metro : } \\
0.237\end{array}$ \\
\hline 5. & 1700000 & 6 & 8 & $\begin{array}{l}- \\
7.0144233\end{array}$ & $\begin{array}{l}110.434 \\
3738999 \\
9997\end{array}$ & $\begin{array}{l}\text { Hotel Patra Jasa: } \\
0.423271649185 \\
\text { Hotel Horison : } \\
0.423271649185 \\
\text { Hotel Grand Candi : } \\
0.336290466121\end{array}$ & $\begin{array}{l}\text { Hotel Patra Jasa: } \\
0.423 \\
\text { Hotel Horison : } \\
0.423 \\
\text { Hotel Grand } \\
\text { Candi : } 0.336\end{array}$ \\
\hline & & & & & & Tidak cocok $=0$ & Cocok $=5$ \\
\hline & & & & & & Presentase Kecocoka & $100 \%$ \\
\hline
\end{tabular}

\section{Analisis Hasil Uji}

Berdasarkan hasil pengujian pada Lampiran 4 menunjukkan bahwa hasil perhitungan nilai preferensi dengan cara manual memiliki sedikit perbedaan dengan hasil perhitungan nilai preferensi dari SPK
Pemilihan Hotel di Kota Semarang dengan Metode FAHP. Perbedaan hasil nilai preferensi dengan cara manual dan dari sistem terlihat pada digit ketiga nilai desimal pada nilai preferensi. Perbedaan disebabkan karena pada perhitungan secara manual nilai desimal 
menggunakan pembulatan tiga digit, sedangkan perhitungan dari sistem tidak menggunakan proses pembulatan.

Sebuah program yang diuji menggunakan metode black-box dikatakan diterima jika fungsi-fungsi yang ada telah memenuhi kriteria evaluasi hasil yang diharapkan. Dapat disimpulkan bahwa SPK HOTEL telah memenuhi persyaratan sesuai spesifikasi sistem yang telah dijabarkan sebelumnya.

Dari hasil pengujian SPK HOTEL ini dapat diketahui bahwa sistem telah memenuhi persyaratan perangkat lunak yang telah didefinisikan yaitu sebagai berikut :

1. Melakukan otentikasi user

2. Manajemen data $u s e r$

3. Manajemen data hotel

4. Manajemen data fasilitas

5. Manajemen data pelayanan

6. Menampilkan data hotel, detail hotel, dan data pencarian hotel

7. Menampilkan peta Hotel dan hasil pencarian peta

8. Menampilkan hasil perangkingan hotel

\section{PENUTUP}

\section{Kesimpulan}

Kesimpulan yang dapat diambil dalam pengerjaan tugas akhir ini adalah dengan dihasilkannya Sistem Pendukung Keputusan Pemilihan Hotel di Kota Semarang Berbasis Web dengan Metode Fuzzy Analytical Hierarchy Process (SPK HOTEL). SPK HOTEL ini menggunakan metode FAHP yang dapat melakukan perangkingan hotel di Kota Semarang. Selain itu, SPK ini juga dilengkapi dengan peta digital dengan Google Maps API untuk memudahkan dalam melakukan pencarian lokasi hotel yang diinginkan.

\section{Saran}

SPK HOTEL ini dapat dikembangkan menjadi berbasis mobile untuk menghasilkan SPK yang dapat diakses menggunakan telepon genggam. Selain itu, penambahan data hotel yang terdapat di Semarang dapat memberikan hasil perangkingan yang lebih beragam.
Pengembangan juga dapat dilakukan dengan penambahan menu untuk mencari arah menuju lokasi hotel agar dapat memberikan kemudahan pengguna menuju lokasi yang diinginkan.

\section{DAFTAR PUSTAKA}

[1] Chang D.Y., 1996, "Applications of Extent Analysis Method on Fuzzy AHP", European Journal of Operational Research.

[2] Dinas Pariwisata dan Kebudayaan Kota Semarang, http://semarang-tourism.com, pada 25 Desember 2012, pukul 20.00 WIB.

[3] Jasril, E. H. dan Afriaty I., 2011, "Sistem Pendukung Keputusan (SPK) Pemilihan Karyawan terbaik menggunakan metode Fuzzy AHP (F-AHP)", Seminar Nasional Informatika 2011 UPN "Veteran" Yogyakarta, Yogyakarta, 17-18 Juni 2011.

[4] Surat Keputusan Menteri Parpostel no Km 94/HK103/MPPT/ 1987

[5] Efraim, T. dkk, 2005, "Decision Support System and Intelligent Systems" (Edisi 7 , Jilid 1), Penerbit Andi, Yogyakarta.

[6] Alonso J. A. dan Lamata, M. T., 2006, "Consistency in the Analytic Hierarchy Process : A New Approach", International Journal of Uncertainty, Fuzziness and Knowledge-Based System.

[7] Sommerville, Ian., 2003, "Software Engineering (Rekayasa Perangkat Lunak)", Erlangga, Jakarta.

[8] Zimmerman, H. J., 1991, "Fuzzy Set Theory and Its Application", Kluwer Academic Publisher, Dordrech.

[9] Veness, Chris. Calculate distance and bearing between two Latitude/Longitude points using Haversine formula in JavaScript. Movable Type Scripts. [Online] 2014. [1 Januari 2014] http://www.movabletype.co.uk/scripts/latlong.html. 